University of Florida Levin College of Law

UF Law Scholarship Repository

UF Law Faculty Publications

Faculty Scholarship

1996

Thinking, Talking and Teaching on Race: Derrick Bell's "The Space Traders"

Katheryn Russell-Brown

University of Florida Levin College of Law, russellbrown@law.ufl.edu

Follow this and additional works at: https://scholarship.law.ufl.edu/facultypub

Part of the Law and Race Commons, and the Legal Education Commons

Recommended Citation

Katheryn K. Russell, Thinking, Talking and Teaching on Race: Derrick Bell's "The Space Traders", 7 J. Crim. Just. Educ. 113 (1996)

This Article is brought to you for free and open access by the Faculty Scholarship at UF Law Scholarship Repository. It has been accepted for inclusion in UF Law Faculty Publications by an authorized administrator of UF Law Scholarship Repository. For more information, please contact kaleita@law.ufl.edu. 


\title{
THINKING, TALKING, AND TEACHING ON RACE: DERRICK BELL'S "THE SPACE TRADERS"
}

\author{
KATHERYN K. RUSSELL \\ University of Maryland at College Park
}

\begin{abstract}
This paper describes and evaluates a writing exercise for an upper level criminal justice course. A hypothetical scenario is used to broach and encourage thoughtful discussion on race and crime. Use of the hypothetical allows students to openly consider issues of race, crime, and criminal justice and the intersections between these areas.
\end{abstract}

The decision to create and teach a course on race, crime, and criminal justice was not easy. The taboo nature of the topic, combined with the wealth of existing research, much of it in conflict, did not make for a professor-friendly undertaking. In fact, fewer than half of the criminology/ criminal justice doctoral programs offer an undergraduate course on race and crime. ${ }^{1}$ Still, given the strong undercurrent of race in almost all discussions of criminolgy and because of my belief that it should be discussed front and center (LaFree and Russell 1993), I decided to plunge in. ${ }^{2}$

Perceptions and beliefs about the race-crime relationship do not operate in a vacuum, but within a larger framework of race relations. ${ }^{3}$ To cultivate an open dialogue about race and crime requires a more general discussion about race, racial attitudes, and racism. With this in mind, I thought as an initial step, it would be important to complete an exercise that would help students critically assess their own beliefs about race.

One successful exercise in expansive thinking is a law school staple, the hypothetical. One of the best known is Professor Lon Fuller's (1949) "The

1 An April 1993 survey of 18 criminal justice/criminology doctoral programs revealed that less than half (7/18) offered a course on race and crime (LaFree and Russell 1993).

${ }^{2}$ Copies of the course syllabus and a selected bibliography on race, criminal justice, criminology, and law are available from the author.

${ }^{3} \mathrm{~A}$ recent survey on race relations between Blacks, Whites, Asians, and Latinos revealed both intergroup unity and dissent (Duke 1994). For a broad ranging discussion of American race relations in general and crime in particular, see Hacker (1992). 
Speluncean Explorers." 4 The value and the strength of metaphor in tackling difficult topics cannot be overstated. Most important, it creates a distance between the reader and the subject, which is critical in addressing a sensitive and difficult issue such as race. ${ }^{5}$ Professor Frances Ansley (1991:1555), discussing a course she taught on race and the law, comments, "I found the subject matter of race as a curricular focus produced tensions well beyond those we all know and recognize as part of the normal course of legal education."

In view of the topic, the next step was to choose a reading that would force students to think outside their own square boxes about race-an area particularly susceptible to personal experience and confirming anecdotal data. 6 I selected Professor Derrick Bell's (1992) "The Space Traders" because it transformed my own thinking on race, racial attitudes, and the U.S. justice system.

Bell's hypothetical scenario presents a provocative and probing picture of interracial and intraracial dynamics. It is the year 2000, and aliens have arrived in the United States. They bear priceless treasures, "gold, to bail out the almost bankrupt federal, state, and local governments, special chemicals capable of unpolluting the environment . . . and a totally safe nuclear engine and fuel" (1992:159-60). In return, the aliens want one thing only: the United States must turn over its entire Black population. The U.S. government is given two weeks to decide whether to accept the offer.

Exactly what fate awaits Blacks if the trade is accepted-chattel slavery revisited or a land of milk and honey-is uncertain. "The Space Traders" chronicles the debates of government officials and interest groups over the two-week period. In Bell's scenario, the government's response to street crime by Blacks has been to barricade the inner cities and impose martial law. Pillage by white-collar criminals-the undergirding of the savings and loan crisis - has been largely overlooked.

Although popular opinion favors the trade, a number of antitrade coalitions form. The Jewish community, fearing that it could be the next trade sacrifice, staunchly opposes the trade. Big business, for business reasons, also weighs in against the trade. The president, however, responding to the political winds, favors the trade. Protrade groups rally to have a 27th Amendment passed. The amendment would constitutionally require

4 In this tale, cave explorers, threatened with starvation, kill and consume the remains of one of their own. Subsequently, the survivors are rescued. Fuller, through hypothetical judicial reasoning, explores the various legal issues raised (criminal charges and available defenses) and how they might be resolved.

${ }^{5}$ Creating a distance between student and topic, so as to foster objectivity, is one of the critical skills one can learn from such an exercise.

6 Professor Gimenez (1989), discussing the value of critical perspective as pedagogy states, "[L]earning, both content and intellectual skills, is most likely to take place when one's common-sense, 'natural' view of oneself and of social reality is questioned" (p. 185). 
Blacks to participate in the trade as part of their special service to the country: "[E]very United States citizen is subject at the call of Congress to selection for special service for periods necessary" (Bell 1992:185). The amendment is ratified by a 70-30 margin, and the Space Traders' offer is accepted.

\section{THE COURSE AND THE STUDENTS}

"Race, Crime, and Criminal Justice" is a 300-level elective course for criminology and criminal justice (CCJS) majors at the University of Maryland, College Park. The spring 1994 semester marked the third semester the course had been offered. This course is designed to expose students to the research and issues surrounding race and crime. In particular, it examines definitional issues, provides an historical overview of the U.S. criminal justice system and its treatment of Whites and Blacks, and considers practical issues, such as disparity and discrimination in the criminal justice system.

To facilitate students participation in class discussion, we placed the chairs in a semicircle formation. Ten percent of the final course grade was based upon participation in class discussion. Further, at the end of each section of the lecture and reading materials, we held a class discussion about how the concepts meshed and conducted a critical assessment of the research. Professor bell hooks' (1994) term "engaged pedagogy" best expresses the goals of the classroom experience. ${ }^{7}$

Of the 54 students enrolled in the spring 1994 course, 83 percent (44 students) were CCJS majors. An even larger proportion, 89 pecent (47), were seniors. Fifty nine percent (32) of the students were males. Whites accounted for 61 percent (34) of the students and Black students comprised 30 percent (16). Of the remaining five students, three were Hispanic and the racial identity of the other two students was unknown. ${ }^{8}$

\section{THE ASSIGNMENT AND THE RESPONSES}

The Space Traders' assignment required students to read Bell's piece and determine whether they believed the trade could take place. Students were then told to write an essay in support of their position. ${ }^{9}$ The primary

7 hooks (1994) uses this term to describe an open and continuous dialogue in the classroom, designed to "create an open learning community" (p. 8) and to foster critical thinking.

8 Whether these students, given their descriptive statistics, had any particular biases regarding race and crime is not known. It is generally believed that Maryland CCJS majors are conservative. My own teaching confirms this. Whether students who enroll in an elective course titled, "Race, Crime, and Criminal Justice" are likely to be more liberal than those who do not is unknown.

9 The actual assignment read as follows: "After reading 'The Space Traders,' write an essay which addresses the following (1) Is the scenario Bell describes plausible or is it incredible? (2) Make a persuasive case for why the Space Traders hypothetical could or could not occur today and (3) You should utilize course materials, newspaper, journal, magazine articles, etc., to make your argument. The assignment must be 3-4 typed pages (750-1000 words)." 
goal of the assignment was to present students with new parameters for thinking about race and crime. The essay assignment was also designed to concretize their thinking by asking them to take a side and to make an argument for or against the space trade.

\section{(In)credibility of the Space Trade}

More than half of the students (55\%) concluded that the space trade Bell described could happen. Interestingly, however, most of these students began their papers by stating emphatically that the space trade could never happen. This student's comment is representative:

When I first read Bell's article on the Space Traders, my first impulse was to laugh because of how exaggerated and far from reality I thought the whole premise was. Yet if one peruses the article just one more time and gives it a second thought, I believe that they may be able to see what I saw.

Strikingly, almost ninety percent $(87.5 \%)$ of the Black students argued that the trade was credible, while just over half $(57 \%)$ of the White students took this position.

\section{Reasons Why a Space Trade Could Happen}

Students who thought the space trade was a real possibility offered several reasons to support their position. One of the most frequently cited was the history of U.S. race relations, which included the use of the law to discriminate against racial and ethnic minorities. Students also commonly referenced the existence of racism in today's society. Noting the relevance of history, one student observed,

The slave codes, black codes, and Jim Crow laws ... the consistent action by the Bureau of Indian Affairs in selling off and exploiting land rights; the enactment of certain laws to contain people in camps during war time ... all examples of how the law has been manipulated in the past to control the "dangerous classes." The Space Traders is a story that merely builds upon history.

Another student compared the space trade to the Jewish Holocaust:

[I]f I was 22 years old living in Germany in 1933 (the year Hitler came to power) and someone told me that six million of my people would be massacred by 1945 , I would have thought it was just as incredible and out of the realm of possibility as many people will think when they read "The Space Traders."

One student commented, "I know that this article isn't a reality, but it does make you stop and think. I mean there is precedent for this type of scenario. As racial tensions continue to rise, do we know what the next century holds?" Another student, after noting that racism existed when this country was founded, dourly concluded, "Racism is the basic unit of our society just as the cell is the basic unit of life." 


\section{Reasons Why a Space Trade Could Not Happen}

Aside from arguments about the existence of extraterrestial beings, most of the students who took the position that the space trade could not happen cited the intrinsic goodwill of humankind. One student wrote, "I feel the majority of U.S. citizens, regardless of color, would not allow this to happen. When unethical situations occur, groups unite to form collective forces against the bad influencs." A few of these students argued that the trade would incite a civil war. Others took a more practical approach, arguing that one trade would beget another and that the sacrificed group would simply be replaced by another group:

[W] hen the rest of the world found out that the U.S. was now rid of its debt, had a perfect environment, and safe machinery, in addition to a reduction of $13 \%$ of its citizenry, the influx of immigrants would be enormous. ... With large rates of immigration, the working and lower class will only expand, and new groups of people will occupy the condition that the blacks once held.

\section{DISCUSSION OF THE RESPONSES}

After the papers were graded and returned, an entire class period was devoted to discussing the article. This dialogue was part of the ongoing "engaged pedagogy." Students were asked to express their feelings about the plausibility of the trade, in view of the course readings as well as their personal experience. In contrast to the written responses, the most vocal comments in class were made by those students who believed a space trade could occur. In some respects, the students' response to Bell's scenario reflect the response we would expect from the larger society. In particular, it is remarkable that such a large percentage (87.5\%) of the Black students thought the space trade could come to pass. Equally remarkable, however, is the fact that more than half of the White students (57\%) had the same response. It is difficult to assess whether these students were cynical or simply realistic. Most important, however, is that an overwhelming number of the students perceive deep racial divisions in this country-both as a general rule and as specifically related to race-crime issues.

\section{NEW KNOWLEDGE, NEW PERSPECTIVES}

"The Space Traders" is the most remarked upon reading I have ever assigned to a class. The feedback from students, including comments made during class, during office hours, and on course evaluations, attests to the challenge posed by this reading. Students responded to both the content and its unique format. They appeared to appreciate the assignment as a nontraditional academic exercise. ${ }^{10}$ Such exercises are particularly valuable tools for managing difficult subfield topics.

${ }^{10}$ Miller (1993) and Toch (1990) describe interesting pedagogical approaches used to broaden criminal justice students' exposure. 
It appears that the two goals of the assignment were met. First, the assignment encouraged students to consider a broader approach when studying race and crime. Specifically, the students expressed an understanding of different perspectives on how race, crime, and criminal justice are related. Their oral and written reflections suggested that the assignment was a valuable experience on an individual level. Second, beyond personal growth, hopefully students will take the skills encouraged by this exercise-analytical and expansive thinking-to their work as criminal justice professionals. Further, the written exercise combined with the discussion may help students deal with other controversial issues in the field (e.g., the death penalty, prison overcrowding). The persistence of the crime problem makes apparent the need to rethink and reformulate existing strategies and paradigms for study.

I plan to make at least two changes when I teach the course again. First, I would assign "The Space Traders" earlier in the semester. In the past, the assignment has been due in early March-almost halfway through the semester. I would consider moving the deadline up to the first month of the semester. This would serve two purposes: it would force students to confront their personal attitudes about race and crime early, and would initiate classroom dialogue on race.

Second, I would consider adding a structured oral component as a graded exercise. Although the class discussed the piece, it was evident that most students did not feel comfortable sharing the views they articulated in their papers. An oral assignment that divided the students into two teams, protrade and antitrade and required them to make thoughtful, well-supported arguments, would further hone their critical abilities. It would also make more clear the compelling arguments on both sides of the race-crime issue.

In any number of ways "The Space Traders" could be used in a survey criminal justice course devoted to race and crime. The "Space Traders" exercise described here is one possible way to broach a discussion on race. Given the salience of race in our study of crime, any exercise that facilitates thoughtful dialogue on race and crime should be encouraged.

\section{REFERENCES}

Ansley, F. (1991) "Race and the Core Curriculum in Legal Education." Califormia Law Review 1511:79.

Bell, D. (1992) "The Space Traders." In Faces at the Bottom of the Well, pp. 158-194. New York: Basic Books.

Duke, L. (1994) "Blacks, Asians, Latinos Cite Prejudice by Whites for Limited Opportunity." Washington Post, March 3, p. A9.

Fuller, L. (1949) "The Speluncean Explorers." Harvand Law Review 616:62.

Gimenez, M. (1989) "Silence in the Classroom: Some Thoughts About Teaching in the 1980s." Teaching Sociology 17:184-91.

Hacker, A. (1992) Two Nations. New York: Scribners.

hooks, bell (1994) Teaching to Transgress: Education as the Practice of Freedom. New York: Routledge. 
LaFree, G. and K.K. Russell (1993) "The Argument for Studying Race and Crime." Joumal of Criminal Justice Education 4:273-89.

Miller, S. (1993) "Narrowing the Distance: Using 'There Are No Children Here' in the Classroom." Joumal of Criminal Justice Education 4:177-87.

Toch, H. (1990) "Falling In Love With a Book." Joumal of Criminal Justice Education 1:24554. 
